\title{
TÓTH IVÁN
}

\section{IRODALMI MINTÁK ÉS HATÁSOK II. MEHMED DRINÁPOLYI BESZÉDÉBEN} (Kritobulos, SH I 14,1-9)*

\begin{abstract}
E tanulmány bemutatja, hogy az egyik utolsó bizánci történetíró, Michaél Kritobulos hogyan alkalmazta az irodalmi utánzás eszközét II. Mehmed szultán drinápolyi beszédében. Megpróbálja feltárni a beszédben olvasható hosszabb történeti ekphrasis irodalmi mintáit és szerepét, majd az orációban található rejtett történetírói reflexiókat vizsgálja. Közismert tény, hogy a klasszikus szerzők történeti szereplőik beszédeiben számos alkalommal implicit módon saját nézeteiket szólaltatják meg a történelemről és a történeti megismerésről. Mehmed beszédének egyes mondatai arra utalnak, hogy e jelenség nemcsak a klasszikus, de a késő bizánci történetírásban is felfedezhető.
\end{abstract}

Kulcsszavak: késő bizánci történetírás, irodalmi utánzás, Thukydidés, történetírói reflexió

Tudvalévő, hogy a történeti munkákba iktatott szónoki beszédek fontos szerepet töltöttek be az ókori és a bizánci historiográfiában: a történetírók segítségükkel árnyalták a beszélő jellemét, tisztázták indítékait, vagy az adott történeti helyzet hátterében meghúzódó okokat, összefüggéseket fedték fel. ${ }^{1}$ Hogy mindezt miként tették, arról Lukianos Hogyan kell történelmet írni? című esszéjének 58. fejezete tájékoztat tömören: „Ha egy szónokló szereplőt kell fölléptetned, beszéljen úgy, ahogy az a leginkább illik a személyéhez és a helyzethez. A beszédének is a lehető legvilágosabbnak kell lennie. Ilyenkor egyébként szónokolhatsz, megcsillogtathatod rétori képességeidet."2 Ahogy az útmutatásból kiderül, a történetírók nagyobb alkotói szabadságot engedhettek meg maguknak beszédírás közben, mint máskor. A jó történetíró azonban még e „felhatalmazás” birtokában is fél szemmel a nagy elődökre tekintett, s beszédeiket utánozta. ${ }^{3}$ Ám ez az utánzás nem a régi mesterek szolgai követését jelentette: az értő közönség elvárta, hogy

* A tanulmány az NKFIH NN 124539 Társadalmi kontextus a szövegkritika tükrében: Bizáncon innen és túl címủ pályázat támogatásával készült.

1 A történetírói beszédek változatos funkcióit röviden számba veszi J. Marincola: Speeches in Classical Historiography. In: A Companion to Greek and Roman Historiography. Vol. I. Ed. J. Marincola. Malden, Mass. - Oxford 2007. 118-132, különösen: 119 sk. Hasonló feladatokat láttak el a beszédek a bizánci történetíróknál is; vö. D. R. Reinsch: Byzantine Adaptations of Thucydides. In: Brill's Companion to Thucydides. Eds. A. Rengakos - A. Tsakmakis. Leiden - Boston 2006. 755-778, különösen: 762.

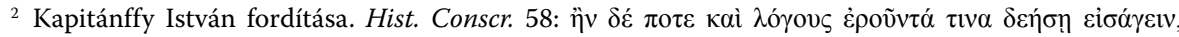

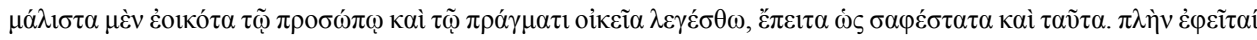

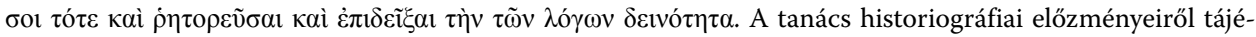
koztat G. Avenarius: Lukians Schrift zur Geschichtsschreibung. Meisenheim am Glan 1956. 149-157 és $H$. Homeyer: Lukian: Wie man Geschichte schreiben soll. München 1965. 275-277.

${ }^{3}$ Lásd Marincola: i. m. (1. jegyz.) 130. 
a kölcsönvett szavakat, gondolatokat, motívumokat a kölcsönvevő kreatív módon ültesse át írásába, így téve azokat a sajátjává. ${ }^{4}$ Következésképp, amikor a beszédeket olvassuk, az irodalmi minták és hagyományok mindig egyedi szőttesében nemcsak a múlt szereplőinek képe rajzolódik ki előttünk, hanem - a szövet fonákján - a történetíróé is. A tanulmányban az utóbbi portréjával foglalkozom. Azt vizsgálom, hogy egyes történetírói (és szónoki) hagyományok, felfogások miként befolyásolták a Konstantinápoly bevételét és II. Mehmed szultán uralkodásának első tizenhét évét feljegyző imbrosi Kritobulost, miközben a török uralkodó drinápolyi beszédét fogalmazta Syngraphé historión $(S H)$ című munkájához. A jelen vizsgálat nem terjed ki az egész beszédre, csak annak egyes részeire: a szultán történeti visszatekintésére (SH I 14,3-9) s az azt bevezető néhány mondatra (SH I 14,1-2). Nem allúziókat, áthallásokat, szövegszerű párhuzamokat keresek elsősorban; ezek nagy részét már feltárták - bár számukat lehetne még gyarapítani, s ezt egy alkalommal majd meg is teszem. Inkább olyan hatásokra próbálok rámutatni, melyek búvópatakként szivárogtak a beszédbe, s éppen ezért könnyü átsiklani fölöttük, noha számos értékes adalékkal bővíthetik tudásunkat a szerző gondolkodásáról és bizonyos történetírói hagyományok továbbéléséről.

Ahogy az eddigiekből is kiderült, a vizsgálandó szónoki beszéd a történetíró alkotása, vagyis (ez) az oráció (is) invenció, ${ }^{5}$ ezért nem is érdemes latolgatni a beszéd és a történeti tények viszonyát, vagyis azt, hogy mit mondott valójában II. Mehmed valamikor 1453 elején a drinápolyi palotában összehívott haditanácson. Az ott elhangzottakról semmit sem tudunk. ${ }^{6}$ Azt viszont tudjuk, hogy a Kritobulos ábrázolta Mehmed Bizánc

${ }^{4} \mathrm{Ha}$ ez nem sikerült, akkor olyan pergőtűznek tehette ki magát a szerző, mint amilyet például Lu-

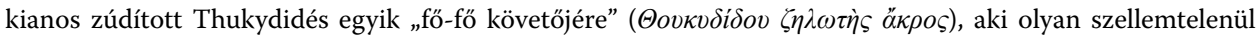
utánozta az athéni historikus írását - többek között a beszédeit -, hogy Lukianos saját bevallása szerint félbehagyta az olvasást, éppen mikor a botcsinálta történetíró Periklés halotti beszédét kezdte el majmolni (Hist. Conscr. 15).

${ }^{5}$ E történetírói találékonyságról s annak a mai (tudományos) felfogástól eltérő ókori megítéléséről, ontológiai státuszáról lásd J. Marincola: On Writing History from Herodotus to Herodian. London 2017. lviii-lx; a témáról kicsit más szemszögből uö: i. m. (1. jegyz.) 120-127. A bizánciak felfogása nem sokban különbözött ókori elődeikétől: „Since every educated Byzantine knew that such speeches were invented by the historian, they were not intended to deceive, and they were therefore not really untruthful. To invent a speech was not to present it as a fact, and was therefore not lying." Az idézet forrása: W. Treadgold: The Unwritten Rules for Writing Byzantine History. In: Proceedings of the $23^{\text {rd }}$ International Congress of Byzantine Studies. Belgrade, 22-27 August 2016. Plenary Papers. Beograd 2016. 277-292, különösen: 278.

${ }^{6}$ Az persze valószínű, hogy a hadjáratot megelőzően sor került tanácskozásra a szultán és az udvar magas rangú tagjai között, s az is elképzelhető, hogy hosszabb beszédek is elhangzottak (Kritobulos azonban biztosan nem volt jelen). A Müller-féle Kritobulos-kiadás apparatusa egy párhuzamos forrásra hívja fel a figyelmet, nevezetesen az ostromot átélő bresciai költő, Ubertino Pusculo Constantinopolis című költeményére, lásd C. Müller (ed.): Critobuli Imbriotae libri quinque de rebus gestis Mechemetis. FHG V/1. Paris 1870. 62, app. ad I 14. Az apparatus szerint (Pusculo szövegét nem láttam) a költeményben három beszéd is olvasható: az első a szultántól (III 23-51), a második a hadjáratot ellenző nagyvezírtől, Haliltól (III 56-92), a harmadik pedig a Mehmed javaslatát támogató Zaganostól (III 103-143). Nem tudom, hogy e három beszéd mennyire lehet segítségünkre a történelmi tények megállapításánál - tartok tőle, hogy semennyire -, mindenesetre formai szempontból érdekes Pusculo eljárása, ha párba állítjuk Kritobuloséval: a bizánci történetírónál ugyanis 
ellen buzdította alattvalóit, méghozzá hosszan: a görög szöveg több mint kilenc oldalt foglal el a mérvadó szövegkiadásban. ${ }^{7}$ Kritobulos él a (Lukianos által is jóváhagyott) lehetőséggel, és megcsillogtatja rétori képességeit. A beszédet tankönyvszerűen építi fel a bemutató (epideiktikos) és a tanácsadó/buzdító (symbuleutikos/paraklétikos) beszédek hagyományos motívumaiból, ${ }^{8}$ miközben müvelt bizánci olvasóiról sem feledkezve meg teleszórja a szöveget irodalmi utalásokkal. Ha szerencsénk van, s épp nemrég olvastuk Thukydidést, akkor csak ritkán kell az apparatus fontiumhoz fordulnunk, hogy észrevegyük az olykor szó szerinti kölcsönzéseket; ${ }^{9} \mathrm{~s}$ bár nem az athéni történetíró az egyetlen irodalmi forrás, ${ }^{10}$ a beszéd kétségtelenül Thukydidés hatását tükrözi. ${ }^{11}$

Kritobulos mindjárt az oráció első mondatában Periklés epitaphios logosának bevezető gondolataira játszik rá, ${ }^{12} \mathrm{~s}$ ezzel a beszéd előadóját, a török szultánt rögtön a nagy athéni államférfival azonos polcra helyezi. ${ }^{13}$ A thukydidési felütést követően azonban a bizánci történetíró eltér a híres, ám sok tekintetben rendhagyó halotti beszédtől: ${ }^{14}$ míg ugyanis Periklés csak röviden tesz említést a korábbi nemzedékekről (őt inkább a jelen

a szultán egyik beszédét sem követi (vagy előzi meg) másik beszéd; az orációk önmagukban állnak, akárcsak Periklés beszédei Thukydidésnél. (Látatlanban ugyan nagyon kockázatos feltételezésekbe bocsátkozni - ezért is a zárójel -, de talán óvatosan felvethetjük, hogy Pusculo, aki görögöt tanulni érkezett Konstantinápolyba, Hérodotos Xerxés-Mardonios-Artabanos beszédhármasa [Hdt. VII 8, $\alpha 1-10, \theta 3$ ] nyomán füzte költeményébe a szónoklatokat.) Pusculóról és költeményéről lásd A. Pertusi (ed.): La caduta di Costantinopoli. Vol. I.: Le testimonianze dei contemporanei. Milano 1976. 198 skk.

${ }^{7}$ D. R. Reinsch (ed.): Critobuli Imbriotae Historiae. CFHB 22. Berlin - New York 1983. 25-34.

${ }^{8}$ A következő lista - a teljesség igénye nélkül - a két beszédtípus hagyományos toposzainak felbukkanását veszi sorra a beszédben: (1) az ősök és dicső tetteik követendő példák (paradeigmata): I 14,1-12; 16,17; (2) az ilyen elődökre nem lehet szégyent hozni: I 14,13; 16,16; (3) a szembenálló erők összehasonlítása (synkrisis): I 16,12-15; (4) a győzelem jutalma és haszna: I 16,3; 16,17; (5) ez a kedvező alkalom (kairos), az égiek jóindulata: I 15; I 16,7; (6) az ellenségtől a múltban elszenvedett károk, a háború igazságossága (dikaion): I, 14,14-19; 16,6; (7) „vagy ők, vagy mi”, az ellenség állandó fenyegetést jelent: I 16,1-5; (8) az ellenség gyenge, a győzelem lehetséges (dynaton): I 14,13; I 16,8-13. A toposzokat a következő művekre támaszkodva álítottam össze: Th. C. Burgess: Epideictic Literature. Chicago 1902 (= Studies in Classical Philology 3 [1902] 89-261), különösen: 211-214; J. Albertus: Die ПАРАК $\Lambda$ HTIKOI in der griechischen und römischen Literatur. Diss. Strassburg 1908, különösen: 55-93 (számos példával); E. Keitel: Homeric Antecedents to the "Cohortatio” in the Ancient Historians. CW 80 (1987) 153-172, különösen: 154-160; S. Usher: Symbouleutic Oratory. In: A Companion to Greek Rhetoric. Ed. I. Worthington. Malden, Mass. - Oxford 2007. 220-235 passim.

${ }_{9}$ Mutatóba előfordulásuk sorrendjében kigyüjtöttem az apparatus fontiumból a Thukydidésnél található párhuzamos helyeket; zárójelbe tettem azokat a locusokat, melyek esetében a szövegkiadó bizonytalan. Reinsch: i. m. (7. jegyz.) 25-34, app. fon.: Th. II 36,1-2; 62,3; 36,3; I 73,2; II 41,4; I 70,5; II 39,1; (11,4; I 78,2); I 70,3; 70,4; 70,8; 70,2; 70,4; 70,9; (70,7; 70,8); 70,8; 70,6; 70,7; 70,8; II 36,3; I 71,1; (142,1; III 59,1); I 33,3-4; 122,1; 78,1-2; 122,2; (II 20,2); I 122,3; (124,3).

${ }^{10}$ Ailios Aristeidéstől, Arrhianostól és Prokopiostól találhatunk még (lehetséges) átvételeket: Reinsch: i. m. (7. jegyz.) $28,29,33$, app. fon.

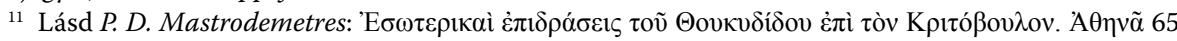
(1961) 158-168, különösen: 163-165; Reinsch: i. m. (7. jegyz.) 50*.

${ }_{12}$ Reinsch: i. m. (7. jegyz.) 25, app. fon. ad I 14,1.

${ }^{13}$ Reinsch: i. m. (1. jegyz.) 765.

${ }^{14}$ Lásd S. Hornblower: A Commentary on Thucydides. Vol. I.: Books I-III. Oxford 1991. 295 (további irodalommal). 
foglalkoztatja), addig Mehmed viszonylag hosszan - majd két oldalon keresztül - ecseteli elődei tetteit. A visszaemlékezésből megtudjuk, hogy a török törzsek a Tauros-hegységtől kiindulva hogyan vették fokozatosan birtokukba az Anatóliai-fennsíkot, majd hogyan keltek át Európába és foglalták el a Balkán-félsziget nagy részét. ${ }^{15}$

A máskor terjedelmes apparatus fontium e sorok esetében kiapad. S noha valóban nehéz lenne konkrét irodalmi párhuzamokat rendelni a vonatkozó paragrafusokhoz, e főleg nép- és földrajzi neveket tartalmazó, zanzásított hadi itinerárium mégsem érdektelen. Ha ugyanis komolyan vesszük Lukianos - alkalmasint az általános véleke-

15 SH I 14,3-9: /Lásd Ázsia lerohanását/ (3) „Kezdetben ugyanis Kilikia és a Tauros hegyeitől elindulva, mint mondottam, csekély haderővel, de annál nagyobb elszántsággal és önbizalommal azonnal megtámadták Lykiát, Pamphyliát és Felső-Phrygiát, meghódították a lydiaiakat, a kariaiakat, a mysiaiakat, az alsóphrygiaiakat, az iónokat s az egész hellén tengerpartot, továbbá leigázták a galatiaiakat, a kappadokiaiakat, a paphlagoniaiakat, a chalypsokat, a bithyniaiakat és a helléspontosiakat, egyszóval az egész területet, amit a Tauros határol, s ami Kilikiától a Fekete-tenger mellet fekvő Sinópéig nyúlik, s amit Alsó-Ázsiának is neveznek, rövid időn belül elfoglalták és szilárdan az uralmuk alatt tartották.” /Lásd a kezdetét az európai átkelésnek/ (4) „Miután mindezeknek az uraivá váltak, és az ottani tengermelléket s annak városait is erősen a kezükben tartották, Prusias városát pedig megtették székhelyüknek, átkeltek a Helléspontoson, de csak egy kis létszámú csapattal, mivel nem nyílt háború céljával, hanem alkalomszerủ kalózkodás és zsákmányolás reményében keltek át, s közben az itteni tengert elkerülték, hiszen azt még a rómaiak uralták. (5) Amikor azonban elfoglalták a Hellé síremléke és a chersonésosi földszoros előtt fekvő hegyfokot, s az ottani erődítményt rohammal vagy csellel bevették, elöször onnan indultak rabolni, és onnan végeztek titkos rajtaütéseket és fosztogatták a környéket rablócsapatokkal” /Európa lerohanása/ (6) „Miután pedig lassanként előrenyomultak és mindig egyre többen lettek, a környező várak közül néhányat részint fegyveres rohammal, részint csellel elfoglaltak és a hatalmukba kerítettek, majd leszálltak a síkra, s ettől fogva már semmi sem állta útjukat: a síkságot birtokukba vették, a falvakat kifosztották, a városokat elfoglalták, a várakat lerombolták, a hadseregeket legyőzték és számos, nagy népet meghódítottak, és - rövidre fogva - kis idő alatt lerohanták egész Thrákiát és Makedóniát, leigázták a belső szárazföldön és az Istros mentén lakó mysiaiakat, valamint az illíreket, triballosokat, helléneket, és legyőztek még sok más népet, erős várakat és számos, nagy várost, amelyek részint a belső szárazföldön, részint a tengerparton feküdtek. (7) De miért is kellene az időt vesztegetnem városok és népek felsorolásával? Minden területet, amit az Istros határol a fekete-tengeri torkolatától felfelé haladva a Saos istrosi torkolatáig, s ami onnan a belföldön át haladva a bosnyákok és a dalmátok és a Saoson innen lakó paionok és illírek között terül el déli irányba egészen az Ión-öbölig, nos, azt mind szilárdan a hatalmuk alá vonták, lakosait pedig az Istroson túl lakó getákkal együtt mind leigázták és adófizetőikké tették. Ám nemcsak ezeket területeket, hanem a Peloponnésost kivéve, bizony, az egész tengerpartot is birtokukba vették, melynek kerülete több mint tízezer stadion. (8) Ezeket azonban egykor nem fáradság nélkül és oly egyszerűen szerezték és őrizték meg mostanáig, mint ahogy azt szóban előadhatjuk, és nem is ellenállás és hatalmas akadályok vagy vérontás és veszélyek nélkül, hanem sok vérrel, sok sebbel és sok verejtékkel s fáradsággal. (9) Hiszen Európában és Ázsiában is számos, hatalmas nép ragadott fegyvert ellenük és küzdött bátran és vitézül mindhalálig a szabadságáért, és mindkét földrészen kőfallal, emberekkel, fegyverrel, lakosai gazdagságával és vitézségével felvértezett számtalan, nagy város kelt fel önmaga védelmére, valamint sok, erős, nehezen vívható vár, rengeteg járhatatlan, kedvezőtlen terep, számos, egymástérő, nem egykönnyen átkelhető folyó és még sok efféle dolog akadályozta őket. Ám leginkább a rómaiak hadai álltak velük szemben szakadatlanul szárazon és vízen, háborúzva és számtalan viszálykodást és harcot támasztva ellenük." 
dést tükröző ${ }^{16}$ - útmutatását, tudniillik, hogy a beszédnek nemcsak a személyhez, de a helyzethez is illeszkednie kell, akkor bizony a kitérő magyarázatra szorul. Hiszen aligha képzelhető el olyan helyzet, melyben a húszas éveibe lépő ifjú szultán rögtönzött történelemórát tart a kormányzat és a hadsereg vezető tisztségviselőinek ${ }^{17}$ a török törzsek terjeszkedéséről és felemelkedéséről.

Kézenfekvő megoldásnak kínálkozik, hogy a győzelmi katalógust a bemutató és a tanácsadó beszédek egyik hagyományos elemének tekintsük, ${ }^{18}$ nevezetesen történeti exemplumnak, melyet a szónok általában arra használ, hogy az általa helyesnek ítélt cselekvésre sarkallja hallgatóságát. ${ }^{19}$ Ez esetben tehát a dicső múlt felidézésével a szultán Konstantinápoly elfoglalására igyekszik embereit bátorítani. Vagy máshonnan, a szerző szemszögéből nézve: Kritobulos követve a klasszikus szónoki/történetírói mintákat, történeti példákkal vértezi fel Mehmed argumentációját. Jóllehet legtöbbször az egyszerű válasz a legjobb megoldás, ezúttal a szultán példatárának néhány sajátossága arra int, hogy ne elégedjünk meg az egyszerű válasszal. Nézzük először az intő jeleket!

A múltidézés egyik feltűnő sajátsága a hossza: ha összevetjük más történeti művek beszédbe ágyazott visszatekintéseivel, akkor a szultán exkurzusa igen terjedelmesnek mondható. ${ }^{20}$ Más szóval, Kritobulos a megszokottnál hosszabban - s ennélfogva részletesebben - tárgyalja az ősök tetteit, aminek nem csak rétorikai okai lehetnek. A másik szembeötlő sajátság tartalmi: a szónok nem egy-egy csatát, háborút emel ki a történelemből példaként, hanem évszázadok hódító terjeszkedését követi nyomon. ${ }^{21}$ Más szóval, Kritobulos vázlatosan ugyan, de átfogó, teljes képet igyekszik adni a törökök hódításairól. ${ }^{22}$ Úgy vélem, mindez arra figyelmeztet, hogy a visszatekintéssel Kritobulosnak nem az volt a szándéka kizárólag, hogy Mehmed beszédét rétorikai szempontból hatásosabbá, meggyőzőbbé tegye, hanem valami más is. A kérdésre, hogy mi lehetett még a szerző intenciója e hosszúra nyúlt visszaemlékezéssel, a választ megítélésem szerint azon irodalmi minták között kell keresnünk, melyek nem a beszéd, hanem az elbeszélés felépítését határozták meg.

${ }^{16}$ A kutatók - joggal - óva intenek attól, hogy Lukianos írásának túl nagy tekintélyt tulajdonítsunk, és normatívnak tekintsük a görög (és római) historiográfia sokszínű és változó elméleti kérdéseivel kapcsolatban; erre figyelmeztet például Marincola: i. m. (5. jegyz.) xxix-xxx, 366-367. Mindazonáltal az 58. fejezet tanácsait nyugodtan tekinthetjük irányadónak, hiszen nem sok olyan szerzőt ismerünk, aki nem ezen elv szerint igyekezett megfogalmazni történeti szereplőinek beszédeit.

17 A hallgatóság összetételéhez és a beszéd fogadtatásához lásd I 13,5; 14,1; 17,1-2.

${ }_{18}$ Ezt meg is tettük, lásd fentebb 8. jegyz., (1)-es pont.

19 Erröl lásd J. Marincola: The Rhetoric of History: Allusion, Intertextuality, and Exemplarity in Historiographical Speeches. In: Stimmen der Geschichte: Funktionen von Reden in der antiken Historiographie. Hrsg. D. Pausch. Berlin - New York 2010. 259-289, különösen: 266-267.

20 Az összevetéshez lásd példákkal Burgess: i. m. (8. jegyz.) 212.

${ }^{21}$ Hasonló átfogó történeti áttekintést találunk Cassius Diónál Caesar beszédében (XXXVIII 37,538,4). Fontos különbség azonban a két visszaemlékezés között, hogy Caesar csak felsorolásszerűen említi a meghódított népeket (XXXVIII 37,5; 38,2; 4), miközben az elődök követendő jellemvonásait dicséri (XXXVIII 38,1; 3); Mehmed beszédében azonban a felsorolás kisebb elbeszéléssé kerekedik.

${ }^{22}$ Ezúttal nem vizsgáljuk, hogy történetileg mennyire pontos Kritobulos vázlata. 
Kritobulos munkájának szerkezeti felépítése Thukydidés művével mutat rokonságot: a bizánci történetíró, hasonlóan athéni elődjéhez, az eseményeket évekre, illetve nyári és téli időszakokra bontva beszéli el. ${ }^{23}$ Thukydidés írása mellett azonban Arrhianos Anabasisa is hatott a bizánci történetíró elbeszélésmódjára, sőt ez a befolyás - ahogy arra a szöveg editora, Diether R. Reinsch figyelmeztet ${ }^{24}$ - erősebb volt, mint az athéni történetíróé. Ennek lehetünk tanúi a Syngraphé historión kezdő sorait és első fejezeteit olvasva.

Míg Thukydidés a peloponnésosi háború leírása elé egy, a görög őstörténetet és a háború előzményeit és okait taglaló prológust illeszt, ${ }^{25}$ addig Arrhianos azonnal Alexandros történetének közepébe vág, s nem ejt szót sem a makedón királyság felemelkedéséről, sem Philippos uralkodásáról, de még Alexandros ifjúkoráról vagy éppen trónra lépésének körülményeiről sem. ${ }^{26}$ A nikomédiai történetíró a prooimion után röviden közli, hogy Philippos Pythodélos archónsága idején meghalt, s a királyságot fia, az akkor húszéves Alexandros vette át. ${ }^{27} \mathrm{~A}$ történet mozgásba lendül, s a történetíró/elbeszélő ezután már csak Alexandrosra és tetteire összpontosít. ${ }^{28}$

Hasonlóan kezd elbeszélésébe Kritobulos is. Miután röviden szól az oszmán uralkodóház eredetéről, ${ }^{29}$ leírását főhősének trónra lépésével kezdi - a nyitómondatot mindjárt az Anabasis kezdőmondatához igazítva ${ }^{30}$-, majd elbeszélésének szálait Mehmed köré szövi anélkül, hogy a korábbi eseményekről említést tenne. ${ }^{31}$ Így az első fejezetekben az ifjú szultán kivételes képességeiről, hódítási terveiről s a megvalósításukhoz szükséges előkészületekről olvasunk. ${ }^{32}$ Âm alig tudunk meg valamit azokról a történésekről, amelyek a mű főtémájához, Bizánc és az Oszmán Birodalom utolsó nagy összecsapásához vezettek. Mindazonáltal az ókori és a bizánci kortörténetek közül néhány igen jelentős munka arról tanúskodik, hogy a kortárs eseményeket magyarázó visszate-

${ }^{23}$ Erről bővebben lásd Reinsch: i. m. (7. jegyz.) $36^{*}-38^{*}, 49^{*}$.

${ }^{24}$ Reinsch: i. m. (7. jegyz.) 66\%.

25 Th. I 1-118.

${ }^{26}$ Vö. A. B. Bosworth: A Historical Commentary on Arrian's History of Alexander. Vol. I.: Commentary on Books I-III. Oxford 1980. 46; Ph. A. Stadter: Arrian's Extended Preface. ICS 6 (1981) 157-171, különösen: 157 sk.; F. Sisti (ed.): Arriano: Anabasi di Alessandro. Vol. I.: Libri I-III. Milano 2001. 305.

27 Arr. An. I 1,1.

${ }_{28}$ Az Anabasis szerkezeti felépítéséről lásd Ph. A. Stadter: Arrian of Nicomedia. Chapel Hill 1980. 76 skk.

29 SH I 4,2.

30 Vö. Arr. An. I 1,1; Kritob. SH I 4,3, illetve Reinsch: i. m. (7. jegyz.) 59*-60*.

31 Kritobulos például nem tesz említést arról, hogy Murád lemondását követően Mehmed 1444 végétől 1446 őszéig már egyszer elfoglalta a trónt (vö. Dukas XXXII 3-5, Laonikos Chalkokondylés: Apodeixis historión [Darkó:] II 121,19-123,6). Murádot azonban végül visszahívták, mert elégedetlenek voltak az ifjú szultán kormányzásával. Kritobulos valószínűleg szándékosan hallgat erről az időszakról; csak Halil pasa kivégzése kapcsán tér ki rá röviden (vö. SH I 76,2). Mehmed első regnálásáról lásd F. Babinger: Mehmed the Conqueror and His Time. Princeton 1978 (= Mehmed der Eroberer und seine Zeit: Weltenstürmer einer Zeitenwende. Münich 1959²). 41-47.

32 SH I 5,21-11,8. 
kintés része volt a Thukydidés fémjelezte történetírói hagyománynak. ${ }^{33}$ Alighanem az athéni történetírót lelkesen olvasó és utánzó ${ }^{34}$ Kritobulos is tisztában volt ezzel az íratlan szabállyal, ${ }^{35}$ mégsem az általa kijelölt irányba indult el, mert kezdetben - mint láttuk más mintát követett; később azonban rálépett a thukydidési ösvényre, és stílszerűen egy szónoki beszédbe ágyazva számolt be a múltbeli eseményekről, így tájékoztatva röviden olvasóit a történeti előzményekről.

Érdemes itt megjegyeznünk, hogy a korábbi hódítások áttekintése után a beszéd a török nép és uralkodói jellemzésével, illetve - ahogy arról az alcím értesít - dicséretével folytatódik. ${ }^{36}$ A dicsérethez Kritobulos ismét Thukydidéstől kölcsönöz, s ezúttal a spártaiakat Athén nyughatatlanságára figyelmeztető korinthosiak szavait (és itt-ott Periklés

33 Marincola (i. m. [19. jegyz.] 262) joggal jegyzi meg: „To revert to historiography, then, when we notice, as we must, that quite a number of historians have a prefatory account that serves as background to the main subject of their histories, we must consider that they are employing a kind of 'archaeology' as Thucydides first did." Az ókori példákat lásd uő: i. m. (19. jegyz.) 262, 11. jegyz. Hasonló bevezetőket bizánci történetíróknál is találhatunk. Darkó Jenő szerint például Kritobulos kortársa, Laonikos Chalkokondylés „épp úgy, mint Thukydides, átnézetet nyújt a hellének megelőző történetéről, csakhogy míg az utóbbi ezt bővebben teszi, tekintettel annak a kornak meglehetős homályos voltára, addig az előbbinél a megelőző történetírók és krónikások óriási tömege a részletes tárgyalást e tekintetben fölöslegessé tette s azért csak a legfőbb pontjaiban megy végig rajta, célja lévén az "E $\lambda \lambda \eta v \varepsilon \varsigma$ és 'P $\omega \mu \alpha$ ĩo közti különbség szabatos kifejtése”. Darkó J.: Adalékok Laonikos Chalkondyles történetírói egyéniségének jellemzéséhez. In: Budapesti VII. ker. külső M. Kir. Állami Főgymnasium 1906-1907. iskolai évi értesítője. Budapest 1907. 3-25, különösen: 8.

${ }^{34}$ Reinsch: i. m. (7. jegyz.) 48*-54* (Kritobulos Thukydidés-imitációjáról), 68*-69* (Kritobulos Thukydidés-kéziratáról).

${ }^{35}$ Erre utalnak a prooimion azon sorai is, melyekben Kritobulos olvasói előtt szabadkozik, amiért e művében nem szól a török nép és uralkodói korábbi tetteiről, lásd SH I 2,1.

${ }^{36}$ SH I 14,10-12: /Lásd e férfiak és uralkodóik dicséretét/ (10) „Ám semmi sem tudta feltartóztatni az elörenyomulásukat, és semmi sem tudott gátat vetni lendületüknek és vitézségüknek addig, míg mindent meg nem hódítottak és teljesen el nem foglaltak, és hatalmukat erősen meg nem szilárdították és minden szempontból biztossá nem tették. S közben mindvégig derék férfiként viselkedtek, és mit sem adtak fel kezdeti elszántságukból és szándékukból. (11) Mert ha az ellenséget legyőzték, még többre törtek, ha pedig vereséget szenvedtek, nem csüggedtek, s jó reményüket sem veszítették el, hanem mindent a saját lelkesedésükre, a jövőbe vetett reményükre, sőt még a bizonytalan szerencsére is bízva, ismét nagy erővel munkához láttak, erejükön felüli elszántsággal s a józan észnek ellentmondó bátorsággal. A veszélyek között bizakodók, a küzdelmekben fáradhatatlanok voltak, s nem haboztak nekifogni ahhoz, amit a maguk számára hasznosnak ítéltek. A kedvező helyzetekben nem tétováztak, hanem gyorsan felmérték a teendőket és tervüket rögtön végre is hajtották. (12) Mindig kedvüket lelték a messzi kalandozásokban, hogy megszerezzék azt, amit még nem birtokolnak, és sohasem maradtak meg a saját földjükön, s azt másoknak sem engedték. A meglévőt semmire sem tartották, mert folyton arra vágytak, amijük nem volt, amit pedig még nem szereztek meg, arra úgy gondoltak, mint a sajátjukra. Csak ideig-óráig élvezték, amijük volt, mert mindig többre vágytak, és folyton azon fáradoztak, hogy megszerezzék és élvezzék, amit még nem birtokolnak. A küzdelmekben és a veszélyekben a testükkel, amit egyáltalán nem kíméltek, úgy bántak, mintha nem a sajátjuk volna, s bár gyakran legyőzték őket, lelkükben mindvégig legyőzhetetlenek maradtak. Így fáradoztak egész életükben, az életet harcnak és küzdelemnek tekintve, és így emelték a birodalmat ily nagy dicsőségre és hatalomra emberrel, pénzzel, fegyverrel, triérésekkel és minden más vagyonnal. A birodalmat hatalmassá és teljesen önállóvá tették háborúban és békében is, majd örökül hagyták ránk." 
halotti beszédének néhány gondolatát) füzi Mehmed beszédébe. ${ }^{37}$ Így lesz a bizánci történetíró tollán a nyughatatlan athéniakból fáradhatatlan és tántoríthatatlan török, a szultán száján pedig aggódó figyelmeztetésből laudatio. Kritobulos azonban, ahogy arra céloztam, nemcsak magasztal, hanem jellemet is rajzol, vagy - s talán így pontosabb - múltat magyaráz. Az irodalmi utánzás segítségével ugyanis szerzőnk a művelt bizánci olvasónak - aki, ne feledjük, behatóan ismerte Thukydidés írását ${ }^{38}$ - azokat a tulajdonságokat mutatja be, vagy, ha úgy tetszik, dekódolja, amelyek birtokában a törökök képesek voltak sikerre vinni hódító vállalkozásaikat. A népleírás ennélfogva nem más, mint függeléke, magyarázata a történeti összefoglalónak.

Miért figyelemre méltó mindez? Azért, mert ha helyes a fenti értelmezés, akkor egyrészt Kritobulos írásművészetéről s annak a Thukydidés és Arrhianos utánzásából fakadó kettősségéről tudhatunk meg többet, másrészt pedig arról, hogy bizonyos elbeszélői minták - az adott szerző kreativitásától függően - milyen kerülőutakon juthattak egy-egy szövegbe.

A beszéd tartalmi és kompozíciós sajátságainak vizsgálata eddig föként Kritobulos írói tevékenységére vetett fényt; a továbbiakban a beszéd azon mondatait veszem szemügyre, amelyek kutatói attitűdjét világítják meg.

Mint arra már többen rámutattak, a történetírók szereplőik szájába adott hoszszabb-rövidebb szövegei közvetett módon olykor arról is vallanak, hogy a szerző miként vélekedett a múlt megismerhetőségéről. Így például a lyd király, Kandaulés megjegyzése arról, hogy a látás megbízhatóbb, mint a hallás, ${ }^{39}$ azt az ismeretelméleti rangsort fogalmazza meg tömören, melyet Hérodotos követett kutatásai közben..$^{40}$ Ahogy Periklés halotti beszédének egyes passzusai is voltaképpen Thukydidés módszertani megfigyeléseit visszhangozzák, mégpedig - Jonas Grethlein szerint ${ }^{41}$ - a következő módon: amikor Periklés arról beszél, hogy Athénnak dicsősége igazolásához nincs szüksége sem Homérosra, sem más költőre, szavai Thukydidés fenntartásainak adnak újra hangot a költészettel szemben; ${ }^{42}$ az államférfi feltűnő szűkszavúsága az elmúlt korok tetteiről pedig a történetíró szkeptikus viszonyát tükrözi a régmúlthoz - azt a viszonyt, amelynek következményeként Thukydidés művében - az epitaphios logoshoz hasonlóan - csak keveset foglalkozik a távoli múlt eseményeivel, saját korát s az abban lezajlott háborút tartva a legjelentősebbnek.

Mielőtt hasonló történetírói reflexiókat keresnénk Kritobulosnál, a fent említett példák sorát egy olyan, szintén thukydidési hellyel szeretném gyarapítani, amely

37 Th. I 70,2-9, illetve II 36,3; 39,1. A párhuzamra többen felhívták a figyelmet: Müller: i. m. (6. jegyz.) 64, app. ad I 14,11-12; Mastrodemetres: i. m. (11. jegyz.) 164-165; Reinsch: i. m. (7. jegyz.) 50*, illetve 28-29, app. fon.

38 Thukydidés bizánci utóéletéről lásd Reinsch: i. m. (1. jegyz.) 755-778.

39 Hdt. I 8,2.

40 J. Marincola: Authority and Tradition in Ancient Historiography. Cambridge 1997. 67; G. Schepens: History and Historia: Inquiry in the Greek Historians. In: A Companion to Greek and Roman Historiography. Vol. I. Ed. J. Marincola. Malden, Mass. - Oxford 2007. 39-55, különösen: 43.

${ }^{41}$ J. Grethlein: The Greeks and Their Past. Poetry, Oratory and History in the Fifth Century BCE. Cambridge 2010. 222-223.

${ }^{42}$ Vö. Th. II 41,4; I 21,1. 
Mehmed drinápolyi beszédében is feltűnik. Thukydidés nemcsak Periklés beszédében, de művének bevezető fejezeteiben is többször utal a múlt megismerhetőségének problémájára. ${ }^{43}$ Nézete szerint a távoli múltat nem lehet pontosan, világosan felfedni, ${ }^{44}$ mivel azt a keveset, amit arról tudunk, csak hallomásból tudjuk, ráadásul a megbízhatatlan költőkön és logographosokon ${ }^{45}$ keresztül. Ezért jobb, ha a történeti kutatást a közelmúlt eseményeinek feltárására korlátozzuk, amit nem hallomás, hanem szemtanúk elbeszélése és autopsia révén rekonstruálhatunk. ${ }^{46}$ Hasonló gondolatokat közvetít az az athéni követ is, aki közvetlenül a háború kitörése előtt így szól a peloponnésosi szövetség tagjaihoz: „Minek hozzuk fel a nagyon régen történt eseményeket, hiszen ezeket inkább az elbeszélésekben hallottak, nem pedig a hallgatók élményei igazolják." 47

A követ szavaiban megbúvó thukydidési gyanakvás a régmúlt történeteivel szemben a XV. századra sem szűnt meg: Kritobulos már a prooimionban hangot ad annak a határozott véleményének, mely szerint a kortörténeti müvek előbbre valóbbak a régi korokat feldolgozó írásoknál. Indokai így szólnak:

Nem utolsósorban a következő okból is szükségesnek látszott számomra a jelen történeti munka [elkészítése]: a háborúk hajdanvolt eseményei ugyanis, igen régiek és hatalmasak lévén, bizonyos tekintetben felfoghatatlanok és meghallgatásra is alig találnak, hiszen idővel úgyszólván idejétmúltakká és hihetetlenekké váltak, vagy éppen a gyakori emlegetésük miatt az emberek már úgy hozzájuk szoktak, hogy oda sem figyelnek rájuk - hiszen minden túlzás csömörhöz vezet, a csömör pedig undort szül. A mostani események viszont, mivel újak, időszerüek és közismertek, könnyen felfoghatóak, tartósan az emlékezetben maradnak, és még inkább csodálatra méltóak időszerüségük miatt; s ez annál inkább így van, minél különlegesebbek és világos és ismert voltuknál fogva hihetőbbek - hiszen az emberek általában az újabb tettekben lelik örömüket $\mathrm{s}$ inkább ezeket követik nyomon szívesen. ${ }^{48}$

${ }^{43}$ Lásd például: Th. I 1,3; 9,4; 10,1-3; 20,1; 20,3; 21,1 .

${ }^{44}$ Más kérdés, hogy kételyei ellenére az ún. archaiologiában Thukydidés fokozódó magabiztossággal tárja elénk a görög őstörténetet, lásd W. R. Connor: Thucydides. Princeton 1984. 27.

${ }_{45}$ Th. 21,1. Grethlein (i. m. [41. jegyz.] 207-209) meggyőzően érvel amellett, hogy a logographos szó a mondatban nem Hérodotosra és a kortárs prózaírókra vonatkozik, hanem a beszédírókra; ezt az értelmezést Grethlein előtt már más is felvetette, lásd Connor: i. m. (44. jegyz.) 28 sk.

${ }^{46}$ Thukydidés persze azzal is tisztában volt, hogy a szemtanúk és az autopsia önmagukban nem garantálják az események hiteles feltárását; erről lásd Marincola: i. m. (40. jegyz.) 67-69.

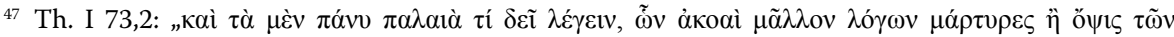

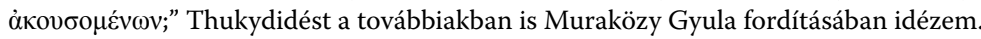

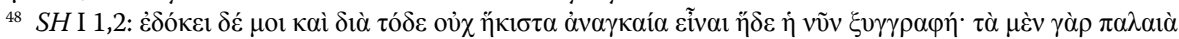

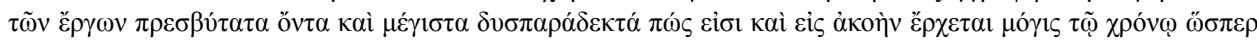

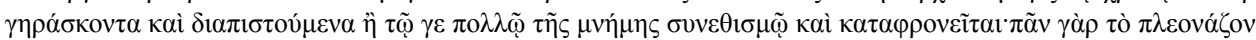

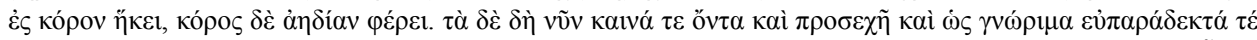

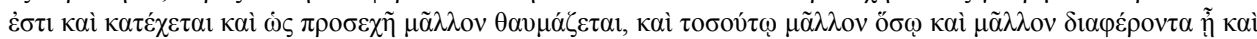

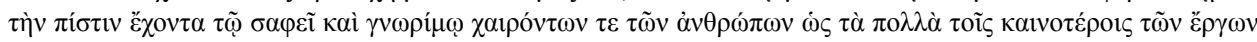

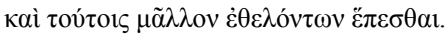


Talán nem túl nagy merészség azt állítani, hogy a fenti véleményt akár Thukydidés is fogalmazhatta volna. Mindenesetre a bizánci történetíró szavai a hajdanvolt tettek

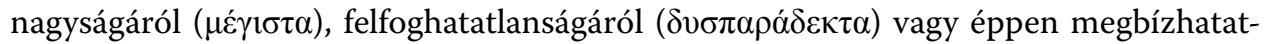
lanságáról $(\delta 1 \alpha \pi \imath \sigma \tau o v ́ \mu \varepsilon v \alpha)$ az athéni történetíró figyelmeztetését idézik, mely szerint a régmúlt eseményeit már nem lehet tárgyilagos vizsgálat alá vonni, mivel az időbeli távolság miatt azok a mendemondák birodalmában ragadtak.

Ennek az elméleti örökségnek a nyomait a szultán beszédében is megtaláljuk, de - mint látni fogjuk - (megint) sajátos formában. Mielőtt Mehmed felelevenítené elődei hódításait, kijelenti, hogy e tetteket közönsége jól ismeri, hiszen az idősebbek maguk is részt vettek a hadjáratokban, a fiatalabbak pedig atyáiktól hallottak e háborúkról. ${ }^{49}$ Ellentétben az athéni követ közönségével, Mehmed hallgatóságának tehát legalább egy része autopsiával rendelkezik arról, amiről a szónok beszélni készül; sőt, a múlt megismerésének ez az egyetlen megbízható módja az ifjabb nemzedékek számára is rendelkezésre áll, ahogy az a szultán következő megjegyzéséből kiderül:

Nem oly régi korok tettei ugyanis ezek, s nem is olyanok, melyek a nagy időbeli távolság miatt homályba vesztek; ellenkezőleg: az elbeszélők történeteit a szemünk igazolja, jobban, mint amit a szemtanúk hírmondása megerősít, hiszen nemrég megtörtént eseményekről van szó. ${ }^{50}$

A folytatásból azt is megtudjuk, hogyan igazolja a látás az elbeszélők történeteit:

Hiszen még most is mindenütt birodalmunkban világosan látni lehet tetteik nyilvánvaló jeleit: a nemrégiben földig rombolt erődítmények és városok falait, a vérüktől szinte még vöröslő, véráztatta földet és még sok ilyesmit, melyek vitézségük és derekasságuk legszebb emlékművei s a veszedelmekben mutatott bátorságuk örökemlékű tanúbizonyságai. ${ }^{51}$

Talán most sem kell bizonygatni, hogy a szultán a valóságban aligha feszegette a múlt megismerésének kérdéseit, $\mathrm{s}$ biztosan nem csomagolta mondandóját görög irodalmi utalásokba, amelyek ismét keresztül-kasul behálózzák a szöveget az apparatus fontium szerint. Reinsch az utóbbi idézet forrásaként a halotti beszédet jelöli meg; ${ }^{52}$ egészen pontosan azt a szakaszt, ahol Periklés arról szónokol, hogy az athéniak mindenütt

49 SH I 14,1.

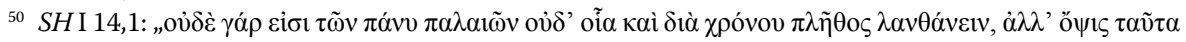

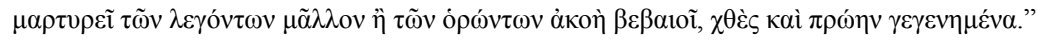

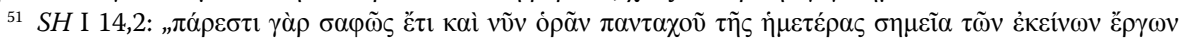

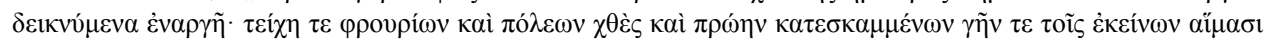
$\sigma \chi \varepsilon \delta$ òv ह̌ं

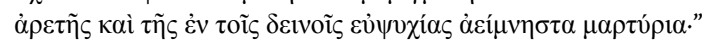

${ }_{52}$ Reinsch: i. m. (7. jegyz.) 26, app. fon.; a párhuzamra korábban már felhívta a figyelmet: Mastrodemetres: i. m. (11. jegyz.) 163 sk. 
otthagyták szigoruk vagy jóságuk maradandó emlékjeleit, ezért nincs szükségük költőkre múltjuk megőrzéséhez. ${ }^{53} \mathrm{Az}$ első mondat mintáját viszont a fentebb idézett athéni követ szavaiban leli meg (másokkal együtt) a német bizantinológus ${ }^{54}$ - megítélésem szerint helyesen, de nem kimerítően. A mondat pontos értelmezéséhez s az intentio auctoris megértéséhez ugyanis még egy párhuzamos helyet figyelembe kell vennünk, amely nemcsak gondolatilag, de nyelvileg is összecseng Kritobulos következő félmondatával: „Nem oly régi korok tettei ugyanis ezek, s nem is olyanok, melyek a nagy időbeli távol-

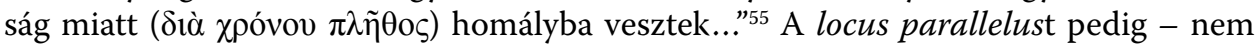
meglepő módon - ismét Thukydidésnél találjuk, aki így kezdi az első caput utolsó mondatát: „Noha a nagy időbeli távolság miatt ( $\delta i \grave{\alpha} \chi \rho o ́ v o v ~ \pi \lambda \tilde{\eta} \theta 0 \varsigma$ ) lehetetlen volt világos képet alkotni az ezt közvetlenül megelőző vagy a még korábbi eseményekről..."56

Ha a vizsgált mondat irodalmi párhuzamainak azonosítása helytálló, akkor a szultán szavait akár az athéni követ kijelentésére adott válaszként is olvashatjuk, vagy ahogy azt a fenti két párhuzamos félmondat mutatja, Kritobulos reflexiójaként a thukydidési hagyományra - arra a hagyományra, melyet, mint az a prooimionból világosan kiderült, a bizánci történetíró is követett, $\mathrm{s}$ amely szerint csak a kortárs eseményeket lehet hitelesen elbeszélni. Mehmednek a múltba túl messzire visszanyúló történeti összefoglalója tehát hitelesítésre szorult, amit Kritobulos meg is tett, méghozzá igen szellemesen az athéni követ és Thukydidés kijelentésének tükröztetésével, majd Periklés szavainak az átültetésével; mindeközben pedig közvetett és inverz módon a saját kutatói attitűdjéről $\mathrm{s}$ arról a sok évszázados hagyományról is vallott, melynek maga is részese volt.

Megint feltehetjük a kérdést (ezúttal utoljára): miért figyelemre méltó mindez. Azért, mert ha ezen olvasat, értelmezés helyes, akkor ismét a hagyomány sajátos továbbélésének lehetünk tanúi, amely, mint a fenti szövegek és irodalmi allúziók mutatják, olykor századokat, sőt évezredeket átívelő „párbeszéddé” alakulhatott.

Végül álljon itt - rövid összefoglalás gyanánt - a tanulmány írójának intenciója: a felhozott példákkal s a kérdésekre adott válaszokkal mindvégig ugyanazt igyekeztem más-más szemszögből megvilágítani, nevezetesen a bizánci történetíró alkotóerejét azt a képességet, melyet az ókori irodalom nyomasztóan gazdag öröksége és tekintélye nemcsak megbénított, de olykor fel is szabadított. ${ }^{57}$

53 Th. II 41,4.

${ }^{54}$ Reinsch: i. m. (7. jegyz.) 25, app. fon.; vö. Müller: i. m. (6. jegyz.) 63, app. ad I 14,1; Mastrodemetres: i. m. (11. jegyz.) 165.

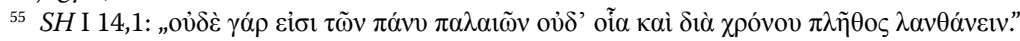

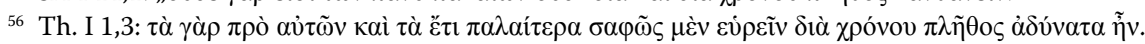

57 Ahogy a Stratis Papaioannou szavait kölcsönvevő Ruth Macrides fogalmaz: „[O]riginality and innovation can be achieved »through choices defined by tradition «, »hidden creatively behind the mask of tradition «" R. Macrides: How the Byzantines Wrote History. In: Proceedings of the $23^{\text {rd }}$ International Congress of Byzantine Studies Belgrade, 22-27 August 2016. Plenary Papers. Beograd 2016. 257-263, különösen: 258. 


\section{SUMMARY}

The present study discusses how ingeniously Michael Kritoboulos, one of the last Byzantine historians used the art of literary imitation and certain elements of the historiographical tradition in the speech of Mehmed II. In the first part of my paper, I make an attempt to identify the literary model and the role of the Sultan's long historical ekphrasis (SH I 14,3-9) then I examine the Byzantine historian's cryptic reflections on his idea of history and methodology (SH I 14,1-2). It is well-known that classical authors often alluded to their view on history and epistemological considerations in the speeches of their historical protagonists. Some passages of Mehmed's oration show that this phenomenon was a characteristic feature not only of the classical historiography but of the late Byzantine as well.

Keywords: late Byzantine historiography, literary imitation, Thucydides, meta-history

\section{TóTH IVÁN}

tivan33@gmail.com

A cikk a Creative Commons Attribution 4.0 International License (https://creativecommons.org/ licenses/by/4.0) feltételei szerint publikalt Open Access közlemény, melynek szellemében a cikk bármilyen médiumban szabadon felhasználható, megosztható és újraközölhető, feltéve, hogy az eredeti szerző és a közlés helye, illetve a CC License linkje és az esetlegesen végrehajtott módosítások feltüntetésre kerülnek. (SID_1) 